\title{
Special issues of IFRS application in Russian organizations
}

\author{
Tatiana Melekhina ${ }^{1 *}$, Elena Sedova ${ }^{2}$, and Irina Karpova $^{3}$ \\ ${ }^{1}$ Moscow University for the Humanities, 5 Yunosti St., Moscow, 111395, Russia \\ ${ }^{2}$ Russian State Geological Prospecting University name Sergo Ordzhonikidze, Miklukho-Maklaya \\ Street, 23, Moscow, 117997, Russia \\ ${ }^{3}$ Plekhanov Russian University of Economics, Stremyanny lane, 36, Moscow, 117997, Russia
}

\begin{abstract}
In modern conditions, Russian accounting is increasingly oriented to international standards. Accounting for leasing relations is also subject to changes that are associated with the transition of Russian accounting to international financial reporting standards (IFRS). In 2016, a new standard was approved for accounting for leases in public sector organizations - the SPS "Leases" (entered into force on January 1, 2018). For other organizations, on October 16, 2018, FAS 25 "Lease accounting" was approved. This standard introduces the type of asset - the right to lease, which represents a new format for accounting methodological documents. The purpose of the study is to consider the features of the application of FAS 25 "Lease accounting" based on the new IFRS 16 "Leases" in accounting for operating leases of Russian organizations. The authors consider the lease relations of economic entities of the Russian economy using the example of pharmacy organizations, in particular, the main aspects of FAS 25, the procedure for accounting for operating leases from the perspective of a lessee and lessor, features of accounting for sublease, leaseback, lease on special terms, as well as disclosure of lease information in accounting (financial) statements. The methodological basis of the study consisted of elements of the accounting method (system of accounts, double entry book-keeping, reporting) and tools of economic analysis (method of comparison, absolute and relative values, tabular and graphical representations of data, coefficient method). As a result of the study, an operating lease accounting mechanism was proposed, which reflects the specifics of pharmacy organizations.
\end{abstract}

\section{Introduction}

The relevance of the research topic is that Russian organizations that do not prepare consolidated financial statements (Law on Consolidated Financial Statements: part 1 of article 2 of Law No. 208-FZ of July 27, 2010) and, therefore, are not required to apply IFRS 16, now will be able to keep a full record of leasing relations taking into account IFRS. Prior to the adoption of FAS 25 "Lease accounting" by Russian standards, the rules for reflecting these transactions were not established in all aspects of accounting and in the

${ }^{*}$ Corresponding author: mele75@yandex.ru 
whole variety of situations that arise. In these cases, the organizations themselves had to establish the rules for accounting for leasing relations in their accounting policies, focusing on IFRS. And although this norm existed, it worked unsatisfactorily in practice.

Nowadays, leasing of immovable property belonging to pharmacy organizations created by privatizing state unitary enterprises into joint-stock companies has become very widespread. Organizations (lessors) leasing property receive income in the form of rent from those objects that they cannot use in their entrepreneurial activity, and organizations (lessees) that do not have their property and financial capabilities to acquire it can receive the property they need for temporary use by entering into a lease (Melekhina, 2006).

According to the Federal State Statistics Service, in 2018 - 2019, business entities that are engaged in the pharmaceutical business (NEO PHARM, SAMSON, Pharmacy chain 36.6, Rigla, Stolichka, Zdorov.ru, etc.) prefer to rent premises for these purposes. Often, they rent it from pharmacy organizations transformed into joint stock companies during privatization. The object of the lease is real estate.

The Civil Code of the Russian Federation provides for a written form for concluding a lease, regardless of the duration of the contract, if one of the parties is a legal entity. In this case, the right to lease property is assigned to the owner of the property.

The contract (Clause 3, Article 607 of the Civil Code of the Russian Federation) must indicate the location, book value, number of rented square meters, and other signs that make it possible to establish the subject of the contract (leased property).

An immovable property lease agreement is considered concluded if it is registered (Clause 2, Article 651 of the Civil Code of the Russian Federation) in the manner established by the Federal Law "On State Registration of Rights to Real Estate" (Federal Law of July 21, 1997 No. 122-FZ), which indicates period of validity for such agreements not less than one year.

In order to bring Russian and international standards closer to each other, in October 2018, the Russian Federal Accounting Standard FAS 25 "Lease accounting" (hereinafter FAS 25) was adopted, the mandatory application of which starts from the reporting for 2022. Earlier application of this document is possible at an earlier date in accordance with the accounting policy of the company, for example, from the financial statements for 2019 (Information message of the Ministry of Finance of Russia dated 01.25.2019 No. ISaccounting-15).

Accounting of lease relations before the adoption of the standard in question had significant differences from the adopted provisions of the new document. The accounting procedure was determined by the parties to the lease by the regulation on the "balance holder" of the leased asset. The lessor was the holder of the balance sheet. Lessee organizations did not consider the leased asset as a right to use the asset. Therefore, there was no question of valuing these assets (Druzhilovskaya, 2018). In exceptional cases, if the leased asset is reflected on the lessee's balance sheet, the value of the property was determined not by the discounted, but by the nominal value of the lease payments, and the amount of the lease debt was determined in the same way.

The use of FAS 25 entails the introduction of appropriate changes and additions to the accounting policies of organizations, since it significantly changes the approach to accounting for leases for both lessees and lessors.

Most often, when switching to FAS 25, lessees and lessors have issues related to the first use of FAS when concluding agreements: recognition of assets and liabilities of each of the parties to the contract; problems of assessing newly recognized assets and liabilities and adjusting previously recognized assets and liabilities; problems of changes in comparative indicators for the previous period. 


\section{Materials and Method}

In the conditions of the development of market relations in our country, pharmacy organizations, among special functions, also perform a social function: they provide the country's population with necessary essential goods - medicines, as well as jobs, including in the field of self-employment, since the pharmacy business accumulates a large the number of small enterprises (Karpova, 2019). The issues of regulation of the market of pharmaceutical services and pharmaceutical products are complex, the solution of which is complicated by the chaotic and spontaneous development of the market. To change the current situation for the better, it is necessary to use special economic instruments, for example, controlling tools (Drury, 2016), which covers integrated regulation in the areas of accounting, analysis and control in organizations (Karpova \& Dontsova, 2019). Despite the fact that the pharmacy business and the small business sector that belongs to it play a significant role in the Russian economy, insufficient attention is paid to regulatory issues in this area, which has a negative impact on the development of this area of the economy. The new FAS 25 developed on the basis of international standards is dedicated to the regulation of leasing relations in commercial organizations and can be applied in the pharmacy business. Since rental payments are part of the entrepreneur's revenue, the application of the new federal standard will play a significant role in the development of this sector of the economy (Trofimova, L., Prodanova, N., Korshunova, L., Savina, N., Ulianova, N., Karpova, T., \& Shilova, L., 2019).

For the lessor, FAS 25 provides only two ways of accounting for property transferred for temporary use: as an operating accounting object or as an object of non-operating (financial) lease.

For pharmacy organizations, an operating lease is economically viable and complying with the requirements of FAS 25, the main feature of which is the preservation of the lessor's economic benefits and risks that are caused by the ownership of the leased asset.

In turn, the transition of such economic benefits and risks to the lessee is the main distinguishing feature of non-operating (financial) leases (Table 1).

Table 1. Description of the distribution of economic benefits and risks

\begin{tabular}{|c|c|}
\hline $\begin{array}{l}\text { Economic benefits and risks remain } \\
\text { with the lessor (operating lease) }\end{array}$ & $\begin{array}{l}\begin{array}{l}\text { Economic benefits and risks are transferred to the lessee (financial } \\
\text { lease) }\end{array} \\
\end{array}$ \\
\hline- & The ownership of the lease is transferred to the lessee \\
\hline- & $\begin{array}{l}\text { The lessee has the right to purchase property at a price that is } \\
\text { significantly lower than the fair value of the leased asset }\end{array}$ \\
\hline $\begin{array}{c}\text { The lease term is significantly less } \\
\text { than the period during which the } \\
\text { leased asset remains usable. }\end{array}$ & $\begin{array}{l}\text { The lease term is comparable to the period during which the leased } \\
\text { item remains usable. }\end{array}$ \\
\hline 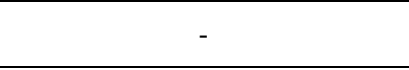 & $\begin{array}{l}\text { The lessee has the right to extend the lease term with rents well } \\
\text { below the market }\end{array}$ \\
\hline- & $\begin{array}{l}\text { The lessee has the right to early termination of the contract and } \\
\text { compensates the lessor for losses associated with the termination }\end{array}$ \\
\hline $\begin{array}{l}\text { The present value of future lease } \\
\text { payments is significantly less than } \\
\text { the fair value of the leased asset }\end{array}$ & $\begin{array}{l}\text { The present value of future lease payments is comparable to the fair } \\
\text { value of the leased asset. }\end{array}$ \\
\hline $\begin{array}{l}\text { The subject of the lease is an object } \\
\text { with an unlimited period of use, } \\
\text { with unchanging consumer } \\
\text { properties over time (land, natural } \\
\text { resources, others) }\end{array}$ & $\begin{array}{l}\text { The subject of the lease is an object that can be used without changes } \\
\text { only by the lessee (reconstruction, modification, others) }\end{array}$ \\
\hline ( & $\begin{array}{l}\text { The lessee incurs losses (profit) from changes in the fair assessment } \\
\text { of the liquidation value of the property (leased asset) }\end{array}$ \\
\hline
\end{tabular}

To classify a lease as operating or financial, at least one of the above circumstances is sufficient. 
Let's consider accounting for operating leases from a lessor in the application of FAS 25.

The cost of fixed assets transferred to operating leases is recorded on account 01 "Fixed assets" (account 03 "Profitable investments in tangible assets") (paragraph 41 of FAS 25/2018) and depreciation is charged, unless operating leases are transferred to fixed assets that are not subject to depreciation (paragraph 50 of the Guidelines for the accounting of fixed assets).

For a separate accounting of the value of transferred fixed assets and the amounts of depreciation accrued on them, it is possible to add analytical accounts or additional subaccounts to accounts $01(03)$ and 02 "Depreciation of fixed assets". This will facilitate the formation of financial statements indicators (paragraph 32 of RAP 6/01 "Accounting for fixed assets", Instructions for the application of the Chart of accounts).

Lease payments are included (paragraphs 5, 7 of RAP 9/99 "Income of the organization"):

in the income from ordinary activities - if the provision of property for lease is the subject of activity of your organization;

in the other income - otherwise.

Operating lease income is recognized evenly or based on a different systematic approach that reflects the lessee's use of the economic benefits of the leased asset (paragraph 42 of FAS 25/2018, paragraph s 12, 15 of RAP 9/99).

Expenses under a lease agreement (including depreciation accrued on fixed assets) are taken into account (paragraphs 5, 11 of RAP 10/99 "Organization expenses"):

in expenses for ordinary activities, if the provision of property for lease is the subject of activity of the organization;

in other expenses - otherwise.

The transfer of fixed assets to operating leases and their return, recognition of income in the form of lease payments and expenses in the form of depreciation is reflected in transactions (table. 2).

Table 2. Accounting of operating leases

\begin{tabular}{|c|c|c|}
\hline Operations content & Debit & Credit \\
\hline \multicolumn{3}{|c|}{ On the date of transfer of the fixed asset to operating leases } \\
\hline \multirow[t]{2}{*}{ The transfer of the fixed asset to operating leases is reflected } & 01 -in lease & $\begin{array}{c}01 \text {-in } \\
\text { organization }\end{array}$ \\
\hline & (03-in lease) & $\begin{array}{c}\text { (03-in } \\
\text { organization) } \\
\end{array}$ \\
\hline $\begin{array}{l}\text { The amount of depreciation on fixed asset transferred to operating } \\
\text { leases is reflected }\end{array}$ & 02-in organization & 02-in lease \\
\hline \multicolumn{3}{|c|}{ Evenly during the term of the lease (usually monthly) } \\
\hline \multirow[t]{2}{*}{ Accrued lease receivable } & 76 & $91-1$ \\
\hline & & $(90-1)$ \\
\hline \multirow[t]{2}{*}{ Accrued VAT on lease payment } & $91-2$ & 68 \\
\hline & $(90-3)$ & \\
\hline \multicolumn{3}{|l|}{ During the lease term on a monthly basis } \\
\hline \multirow[t]{3}{*}{$\begin{array}{l}\text { The amount of accrued depreciation for the fixed asset transferred to } \\
\text { operating leases is reflected in the accounts of accounting }\end{array}$} & $91-2$, & 02-in lease \\
\hline & 26 , & \\
\hline & 20 & \\
\hline \multicolumn{3}{|l|}{ On the date the lessee returns the fixed asset } \\
\hline \multirow[t]{2}{*}{ The return of the fixed asset from the lessee is reflected } & 01-in organization & 01-in lease \\
\hline & $\begin{array}{c}(03 \text {-in } \\
\text { organization }) \\
\end{array}$ & (03-in lease) \\
\hline Depreciation amount on the returned fixed asset is reflected & 02-in lease & $\begin{array}{c}02 \text {-in } \\
\text { organization }\end{array}$ \\
\hline
\end{tabular}

Information about the objects of accounting for operating leases is disclosed in the 
financial statements of the organization (balance sheet; statement of financial results; statement of cash flows; explanations of the balance sheet and statement of financial results).

Let's consider the reflection of the accounting for operating leases in the balance sheet:

The residual value of the fixed assets in operating leases is given in sec. I "Non-current assets" of the balance sheet as indicators by the lines (paragraphs 11, 35 of RAP 4/99, Letter of the Ministry of Finance of Russia dated 30.01.2006 N 07-05-06/16):

1150 "Fixed assets" - if the lease contains assets that were previously used by a pharmacy organization. If the residual value of such fixed assets is significant for the pharmacy, the latter is indicated on the independently entered line "Leased fixed assets" or disclosed in the explanations (paragraph 32 of RAP 6/01);

1160 "Profitable investments in material assets" - if the lease contains assets specially acquired for this purpose. But if the residual value of actually not used profitable investments in tangible assets is significant, we recommend indicating it in the independently entered line "Not leased out profitable investments in tangible assets" or disclose it in the explanations (paragraph 32 of RAP 6/01).

Lease receivables must be reflected in sec. II "Current assets" (Kiryanova \& Sedova, 2014). Long-term and short-term receivables from operating leases are recommended to be included in the indicators in additional lines detailing the indicator of line 1230 "Accounts receivable". If the information on this receivable is significant, it is shown separately (in independently entered lines) (paragraphs 11, 19 of RAP 4/99).

Debt to lessees on received advances are shown net of VAT charged on advance payments (prepayments) (Letter of the Ministry of Finance of Russia dated 09.01.2013 N 07-02-18/01). If the amount is not significant, it is reflected in the indicator (paragraphs 11 of RAP 4/99):

- line 1450 "Other liabilities" in sec. IV "Long-term liabilities" - in terms of long-term operating lease debt;

- line 1520 "Accounts receivable" in sec. V "Short-term liabilities" - in terms of shortterm debt.

Significant information on accounts receivable under operating leases is reflected in additional lines detailing these indicators (paragraph 11 of RAP 4/99, Letter of the Ministry of Finance of Russia dated 01.24.2011 N 07-02-18-18/01).

Let's consider the reflection of the accounting for operating leases in the statement of financial performance.

Information on income in the form of lease payments (excluding VAT) must be reflected (18 of RAP 9/99):

- in line 2110 "Revenue", if it is an income from ordinary activities (paragraph 5 of RAP 9/99);

- in line 2340 "Other income" if the income from the lease of property is not income from ordinary activities (paragraph 7 of RAP 9/99).

If lease payments make up five or more percent of the organization's total income for the reporting period, this indicator should be reflected in separate lines detailing the above lines (paragraph 18.1 of RAP 9/99).

Income related to variable lease payments is allocated separately if this information is significant (paragraph $47(\mathrm{~g})$ of FAS 25/2018).

Information on expenses related to operating lease items (in particular, the amount of accrued depreciation) is reflected (paragraph 21 of RAP 10/99):

- in line 2120 "Cost of sales", if the costs relate to the ordinary activities of the organization (paragraphs 5, 9 of RAP 10/99);

- in line 2350 "Other expenses" if the expenses are not related to the ordinary activities 
of the organization (paragraph 11 of RAP 10/99).

The amounts of expenses related to the operating lease income highlighted in the statement of financial performance should be allocated separately (paragraph 21.1 of RAP 10/99). In addition, other income and related expenses can be shown shortly (paragraph 18.2 (b) of RAP 9/99, paragraph 21.2 of RAP 10/99).

Let's consider the reflection of the accounting for operating leases in the statement of cash flows

In the statement of cash flows, lease payments (excluding VAT) received under an operating lease agreement, regardless of whether the leasing of property is the subject of the organization's activity or not, is reflected in line 4112 of the section "Cash flows from current operations" [p. 9 (b) of RAP 23/2011 "Statement of cash flows"]. VAT is reflected in the statement of cash flows separately (shortly for all operations).

Let's consider the reflection of the accounting for operating leases in the notes to the balance sheet and statement of financial results

When compiling an explanation using the forms contained in the Example for filling out explanations, data is provided on the residual value of the fixed assets leased to operating leases in line 5280 "Leased fixed assets that are on the balance sheet" in table 2.4 "Other uses of fixed assets". Information on debt under a lease must be disclosed in the tables of sec. 5 "Receivables and payables"

It is also necessary to include the information provided for in paragraphs 45,47 of FAS 25/2018 (the nature of the lease activity: whether the provision of fixed assets for operating leases is the main type of activity, types of fixed assets provided for lease, etc. (paragraph 45 (a) FAS 25/2018) in the explanations of the balance sheet and the statement of financial results.

Let's proceed to the accounting of the lease from the lessee in accordance with FAS 25

The leased fixed asset can, as before, be taken into account on the off-balance sheet account 001 "Leased fixed assets" only taking into account the following: the agreement does not provide for the transfer of ownership or the possibility of redemption at a price significantly lower than fair value and the fixed asset cannot be subleased. (paragraph 12 of FAS 25/2018, Instructions for the application of the Chart of accounts). At the same time, the leased object can be taken into account on an off-balance account in any of the cases specified in (paragraph 11 of FAS 25/2018):

- rental period - 12 months or less;

- the cost of a similar new fixed asset does not exceed 300,000 rubles. You can receive economic benefits from a leased fixed asset regardless of other assets;

- you have the right to apply simplified methods of accounting, including simplified accounting (financial) statements.

Lease payments, depending on the purpose of using the fixed asset, are recognized as expenses for ordinary activities or other expenses.

Upon receipt of the fixed asset, an asset transfer form drawn up by the lessor is signed. We recommend to have an inventory card for a leased fixed asset and take it into account using the inventory number assigned by the lessor.

Leased fixed assets are recorded in off-balance sheet account 001 "Leased fixed assets" at the value specified in the contract as of the date of receipt of the property under the act of transfer and acceptance (Instructions for the application of the Chart of accounts).

Lease payments are recognized as an expense evenly, for example, monthly on the last day of the month. It is possible to use another way reflecting the nature of the use of economic benefits from the leased fixed asset (paragraph 11 of FAS 25/2018, paragraphs 16,18 of RAP 10/99 "Organization expenses"). In this case, the lease is recognized in expenses in proportion to the volume of products manufactured using the leased fixed assets (table 3). 
Table 3. Lease accounting

\begin{tabular}{|c|c|c|c|}
\hline Contents of operation & Debit & Credit & Operation reflection period \\
\hline $\begin{array}{c}\text { If the leased object is used in the production or sale of products, sale of goods, performance } \\
\text { of work, provision of services (paragraph 5 of RAP 10/99) }\end{array}$ & $\begin{array}{c}20 \\
(44\end{array}$ & 76 & $\begin{array}{c}\text { Monthly during the period } \\
\text { of lease }\end{array}$ \\
\hline $\begin{array}{c}\text { Lease payments are recognized as } \\
\text { expenses on ordinary activities }\end{array}$ & $\begin{array}{c}\text { or other) } \\
\text { orection or sale of products, sale of goods, }\end{array}$ \\
\hline \multicolumn{3}{|c|}{$\begin{array}{c}\text { If the leased object is NOT used in the production or } \\
\text { performance of work, provision of services (paragraph 11 of RAP 10/99) }\end{array}$} \\
\hline $\begin{array}{c}\text { Lease payments are recognized as } \\
\text { other expenses }\end{array}$ & $91-2$ & 76 & $\begin{array}{c}\text { Monthly during the period } \\
\text { of lease }\end{array}$ \\
\hline
\end{tabular}

If under the terms of the contract the lessee must make repairs, then the costs of the current repairs and (or) overhaul of the property received for rent are written in the entries (Table 4).

Table 4. Accounting for repair costs

\begin{tabular}{|c|c|c|c|}
\hline Contents of operation & Debit & Credit & Operation reflection period \\
\hline $\begin{array}{c}\text { If the leased object is used in the production or sale of products, sale of goods, performance } \\
\text { of work, provision of services (paragraph 5 of RAP 10/99) }\end{array}$ \\
\hline $\begin{array}{c}\text { The costs of repairing property } \\
\text { received for lease are recognized } \\
\text { as expenses for ordinary activities }\end{array}$ & $\begin{array}{c}20 \\
(44 \text { and } \\
\text { other) }\end{array}$ & $\begin{array}{c}60 \\
(70,69 \\
\text { and other) }\end{array}$ & In the completion period \\
\hline \multicolumn{3}{|c|}{$\begin{array}{c}\text { If the leased object is NOT used in the production or sale of products, sale of goods, } \\
\text { performance of work, provision of services (paragraph 11 of RAP 10/99) }\end{array}$} \\
\hline $\begin{array}{c}\text { The costs of repairing property } \\
\text { received for lease are recognized } \\
\text { as other expenses }\end{array}$ & $91-2$ & $\begin{array}{c}60 \\
(70,69 \\
\text { and other) }\end{array}$ & In the completion period \\
\hline
\end{tabular}

The costs of improving the leased property are reflected in the general manner provided for accounting for the costs of improving and restoring the fixed assets.

If under the contract the capital investments made in the leased fixed asset are the property of the lessee, then they must be taken into account as the fixed asset. In this case, the capital object will be capital investments in the form of inseparable improvements to the leased fixed assets. The value of such property is repaid by depreciation over its useful life, which is usually equal to the remaining lease term (Table 5).

Table 5. Accounting for capital investments in the form of inseparable improvements in leased property

\begin{tabular}{|c|c|c|c|}
\hline Contents of operation & Debit & Credit & $\begin{array}{c}\text { Operation reflection } \\
\text { period }\end{array}$ \\
\hline $\begin{array}{l}\text { Capital investment in leased property is } \\
\text { reflected }\end{array}$ & 08 & $\begin{array}{c}60 \\
\text { (23 and other) }\end{array}$ & $\begin{array}{l}\text { In the completion } \\
\text { period }\end{array}$ \\
\hline $\begin{array}{l}\text { Capital investments in the form of } \\
\text { inseparable improvements in leased } \\
\text { property are reflected as fixed assets }\end{array}$ & 01 & 08 & $\begin{array}{l}\text { At the date of adoption } \\
\text { of inseparable } \\
\text { improvements in the } \\
\text { quality of fixed assets }\end{array}$ \\
\hline $\begin{array}{c}\text { Depreciation on inseparable } \\
\text { improvements is accrued: }\end{array}$ & & & $\begin{array}{l}\text { Monthly during the } \\
\text { period of lease }\end{array}$ \\
\hline $\begin{array}{l}\text { - if you use the fixed assets in the } \\
\text { production or sale of products, sale of } \\
\text { goods, performance of work, provision of } \\
\text { services; }\end{array}$ & $\begin{array}{l}20 \\
\text { (44 or } \\
\text { other) }\end{array}$ & 02 & \\
\hline - in other cases & $91-2$ & 02 & \\
\hline $\begin{array}{l}\text { Depreciation accrued on inseparable } \\
\text { improvements is written off }\end{array}$ & 02 & 01 & $\begin{array}{l}\text { At the date of lease } \\
\text { completion }\end{array}$ \\
\hline
\end{tabular}


If the agreement provides for the transfer to the lessor of the capital investments made by the lessee and compensation for the costs incurred by him immediately upon completion of work, then they are written off to settlements with the lessor (table 6).

Table 6. Accounting for capital investments when transferring capital investments that are not an inseparable improvement from the lessee to the lessor

\begin{tabular}{|c|c|c|c|}
\hline Contents of operation & Debit & Credit & Operation reflection period \\
\hline $\begin{array}{c}\text { Capital investment in leased } \\
\text { property is reflected }\end{array}$ & 08 & $\begin{array}{c}60 \\
(23 \text { and others })\end{array}$ & In the completion period \\
\hline $\begin{array}{c}\text { The costs of inseparable } \\
\text { improvements are written off to } \\
\text { settlements with the lessor }\end{array}$ & 76 & 08 & $\begin{array}{c}\text { On the date of transfer of } \\
\text { inseparable improvements } \\
\text { to the lessor }\end{array}$ \\
\hline $\begin{array}{c}\text { Cost compensation received from } \\
\text { the lessor }\end{array}$ & 51 & 76 & $\begin{array}{c}\text { On the date of receipt of } \\
\text { funds }\end{array}$ \\
\hline
\end{tabular}

When the leased property is returned, the fixed asset value is written off from the offbalance sheet account 001 "Leased fixed assets" when it is returned to the lessor under the act of return of the leased property, and the inventory card reflects the retirement of the leased asset.

In the case of preferential leases, the market level of lease payments is used to determine the gross value of the lease. The lessor's accounting at the time of the start of the lease provides for the reflection of deferred expenses as the difference between the actual amount of the lease payments under the contract and the market level of lease payments.

Under the gratuitous use agreement, deferred expenses are recognized at the market value of the lease payments. The resulting difference between actual and market lease payments is included in expenses of the current period. Current period income includes the amount that the lessor considers as deferred income. Thus, the financial result from this operation will be "zero".

The sublease agreement provides for the provision of property to the sublessee (the subject of the agreement) for a fee during the validity of the concluded agreement for temporary possession and (or) temporary use.

The lessee (intermediate lessor) reflects the transactions both as a lessee (as part of a lease agreement) and as a lessor (as part of a sublease agreement).

As part of a leaseback agreement, a relationship under which the seller-lessee transfers the asset to the buyer-lessor and leases the asset back from the buyer-lessor, the main regulatory document is Russian Accounting Principle (RAP 9/99). In this case, the sellerlessee will show the sale of the asset in his account, and the buyer-lessor will reflect the purchase of the asset in his account.

\section{Results}

The pharmaceutical business in Russia, an integral part of which is the production of medicines and materials used for medical purposes, has generally tended to grow over the past seven years. This is evidenced by the results of a study of key financial indicators of enterprises representing this area (Fig. 1). 


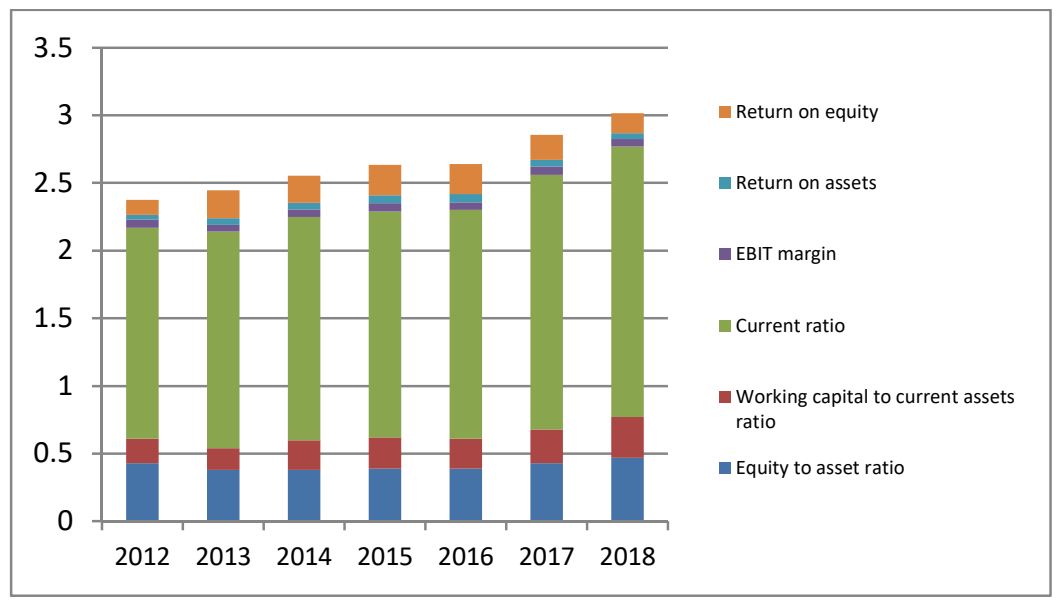

Fig.1. Dynamics of key financial indicators of manufacturers of pharmaceutical products and materials in Russia (Source: Russian State Statistics Service)

Of all the indicators presented in the whole industry for the production of medicines and materials used for medical purposes, such an indicator as EBIT margin decreased in recent years: in $2017-6.2 \%$, in $2018-5.4 \%$. This may indicate problems associated with the sale of finished products and goods. One of the negative factors may be the lack of sales outlets, i.e. pharmacies. This is due to the fact that most pharmacies that do not have a network were forced to lease their premises in order to support the main activity: retailing drugs in specialized stores (pharmacies), OKVED code 47.73 (Russian National Classifier of Types of Economic Activity).

For example, the financial situation of LLC Pharmacy No. 206 on Ryazansky Prospekt worsened. In 2017, this organization's revenue indicator decreased by 11.6 million rubles compared to 2016. Therefore, the management decided to lease the basement. In 2018, revenue in relation to 2017 increased by 1.3 million rubles and amounted to 42.5 million rubles. The share of this type of activity in the total revenue is only $5 \%$. In this case, the proceeds are recorded on credit Account 91 "Other income and expenses". It is advisable for this organization to lease at least half of available space in an operating lease and apply FAS 25.

Another pharmacy organization CJSC Pharmacy No. 72 at Avtozavodskaya, having received a loss on sales of 2.5 million rubles in 2015, was forced to lease a significant part of the available space. In 2016, the organization received profit from sales of 429 thousand rubles, and in 2018 - 509 thousand rubles. For 2018, revenue amounted to: total - 8734 thousand rubles, including from the lease of 5770 thousand rubles $(66 \%$ share in total revenue) and from the sale of products, goods (works, services) 2964 thousand rubles (34\% share in total revenue). The current main type of activity of the organization is: 68.20.2 Lease and management of own or leased non-residential real estate. Thus, we can state that a way out of the crisis for pharmacy organizations is letting the maximum amount of available space for operating lease. Pharmacy No. 162 "PHOENIX" leased all available areas to the largest network pharmacy organization LLC "NEOFARM". Having survived the crisis financial state for the period of 2012-2015, in 2018 Pharmacy No. 162 "PHOENIX" has a total revenue of 16,382 thousand rubles, including the share of rental income in total revenue of $62 \%$ (10 150 thousand rubles).

In general, it is worth noting the steady dynamics of key financial indicators of the industry, the type of activity of which is according to OKVED: 68. Operations with real 
estate (according to the site https://www.testfirm.ru/keyrates/).

Pharmacy organizations - lessors decide on their own which year to start applying FAS 25: starting from reporting for the period from 2022 or earlier. If the organization decides to apply this standard, then it should determine the procedure for the first application and disclose it in the notes to the accounting (financial) statements.

For those pharmacy organizations that kept records of leases on the basis of paragraph 7.1 of Accounting Principles RAP 1/2008 "Accounting policies of an organization", i.e. in accordance with IFRS, transition procedures and adjustments to accounting indicators when applying the new standard are not required. An exception to the rule will be pharmacy organizations that did not apply IFRS 16, but IAS 17 to operating lease agreements, which is very rare in pharmacy organizations.

For pharmacy organizations that keep records of leases according to Russian standards, it is necessary to highlight agreements for the application of FAS 25 and verify compliance with the classification conditions of objects of lease accounting, as well as compliance with other key provisions of the new standard, which were considered in the paper.

A pharmacy organization has the right not to apply FAS 25 during the transitional period until 2022. Also, the lessee has the right to apply the simplified accounting procedure provided for by FAS 25. This procedure is provided for all lessees in relation to short-term lease contracts and (or) lease of low-value property, and for lessees entitled to apply simplified accounting methods - in relation to any contracts.

The adoption of a decision on the application of the simplified method of accounting for leases entails the recognition of the date of application of FAS 25, as well as the right to use the asset and the lease liability for that date. In this case, the right to use the asset will be measured at its fair value, and the liability - at the present value of the remaining unpaid rental payments. Any differences associated with the transition to accounting under the newly introduced standard are attributable to retained earnings, and there is no need to recalculate comparative data for the previous year - a retrospective effect on any other accounting objects is not recognized.

\section{Discussion}

In the process of transition of Russian accounting to IFRS, the procedure for adoption and approval of new Russian standards, which are designed to accumulate the modern experience of IFRS and features of the national economy, was significantly complicated. This procedure includes:

- approval (revision) of the Standard Development Program;

- development of draft new federal standards;

- public discussion of draft standards and adoption of their final version following a public discussion;

- examination of draft standards (based on the results of a public discussion of the draft FAS, the developer can finalize the text of the draft taking into account the comments received. The final version is sent for consideration to the Council on Accounting Standards created under the Ministry of Finance of Russia and consisting of representatives of state and non-state accounting regulation entities);

- approval of federal accounting standards.

The development and approval of federal accounting standards undergo state and public regulation, which is an indicator of a new stage in the development of the domestic accounting methodology, since some of the functions of accounting regulation that previously belonged to the state are transferred to the public represented by non-state regulatory entities. 
For example, the draft FAS 25 was posted for public discussion in accordance with the Federal Law "On accounting" in the public domain until 10.10.2017 on the official website of the Ministry of Finance of Russia. The discussion was actively attended by the largest representatives of the subsoil use sector, such as SURGUTNEFTEGAZ OJSC, MMC NORILSK NICKEL PJSC (NORNICKEL), ROSNEFT PJSC, the comments and suggestions of which were taken into account in FAS 25.

The new standard was based on the division of the lease by the lessor into operating and non-operating (financial), and also took into account other areas of the new lease IFRS IFRS 16 "Leases".

\section{Conclusion}

According to the authors of the paper, for the transition to lease accounting in accordance with FAS 25:

1. Pharmacy organization - lessor is obliged to start applying FAS 25 starting with the accounting (financial) statements for 2022. If such a decision is made before 2022, then the latter shall be disclosed in the accounting (financial) statements of the organization.

2. The consequences of changes in the accounting policies of the pharmacy organization associated with the application of FAS 25 are reflected retrospectively. To this end, the lessee can simultaneously recognize the right to use the asset and the lease liability with the difference in retained earnings attributed to each contract at the end of the year preceding the year starting from which FAS 25 is applied. In this case, retrospective influence on other accounting objects is not recognized. Comparative data prior to the application of FAS 25 are not restated. The right to use the asset is measured at fair value, and the cost of the lease obligation is measured at the present value.

3. A pharmacy organization that is under the general taxation regime may not apply this federal standard if the relations of lease agreements expire before the end of the year, starting with the reporting for which FAS 25 is applied.

4. Also, a pharmacy organization, which has the right to apply simplified methods of accounting, can begin to apply the provisions of this standard only under contracts whose execution begins on January 1, 2022.

5. The pharmacy organization discloses the application of FAS 25 in accounting policies from the date of application of the standard in question.

6 . The considered changes and additions related to the application of the new federal standard (FAS 25) will lead to an increase in the reliability of the accounting (financial) statements of pharmacy organizations regarding lease accounting, which will positively affect the entire financial and economic activities of pharmacy organizations.

7. As part of the study, the reporting of a number of Moscow pharmaceutical organizations with a different share of rental payments, including those in which the share of proceeds from the lease of premises for operating leases is more than $50 \%$, was analyzed. The results of the analysis of the accounting (financial) statements of pharmacy organizations, the most important segment of the pharmaceutical industry, indicate the appropriateness of applying the new federal standard: total revenue (as well as only from lease) in the analyzed period has positive dynamics, its growth rate is higher during application of FAS 25 (2019). The financial results (by types) are growing, the share of gross and operating profit in revenue and the share of other income in revenue increase. It can be assumed that the given trend will have an upward trend, since the application of the new standard allows determining the revenue from lease payments more accurately. 


\section{References}

1. Civil Code of the Russian Federation (Part Two) dated 26.01.1996 N 14-FZ (as amended on 18.03.2019, as amended on 03.07.2019) Art. 608,609,651. www.consultant.ru.

2. Federal Law of July 21, 1997 N 122-FZ "On state registration of rights to real estate and transactions therewith", www.consultant.ru.

3. Order of the Ministry of Finance of Russia dated December 31, 2016 N 258n "On approval of the federal accounting standard for organizations of the public sector "Lease", www.consultant.ru.

4. Order of the Ministry of Finance of Russia dated 10.16.2018 N 208n "On approval of the Federal Accounting Standard FAS 25/2018 "Accounting for leases" (Registered in the Ministry of Justice of Russia on 25.12.2018 N 53162). www.consultant.ru.

5. Russian Accounting Principle RAP 4/99 “Accounting statements of an organization" (Approved by order of the Ministry of Finance of Russia dated 06.07.1999 No. 43n.). (as amended on 08.11.2010, as amended on 29.01.2018). www.consultant.ru.

6. Russian Accounting Principle RAP 6/01 "Accounting for fixed assets" (Approved by order of the Ministry of Finance of Russia dated 30.03.2001 No. 26n.), (as amended on 16.05.2016). www.consultant.ru.

7. Russian Accounting Principle RAP 9/99 "Organization income" (Approved by order of the Ministry of Finance of Russia dated 06.05.1999 No. 32n.), (as amended on 06.04.2015). www.consultant.ru.

8. Russian Accounting Principle RAP 10/99 “Organization expenses" (Approved by order of the Ministry of Finance of Russia dated 06.05.1999 No. 33n.), (as amended on 06.04.2015). www.consultant.ru.

9. Information message of the Ministry of Finance of Russia dated 25.01.2019 No. I ISaccounting-15 "On the Federal Accounting Standard FAS 25/2018 "Accounting for leases". www.consultant.ru.

10. International Standard for Financial Reporting (IFRS) 16 "Leases" (entered into force on the territory of the Russian Federation by Order of the Ministry of Finance of Russia dated 11.06.2016 N 111n) (as amended on 16.09.2019) www.consultant.ru.

11. C. Drury, Management and production accounting. Introductory course.(Moscow, Russia, Unity-Dana, 2016).

12. T.Yu. Druzhilovskaya, International accounting, 17-18 (2018)

13. I.F. Karpova, Materials of the inter-university collection of scientific papers and the results of joint research projects "Accounting, control and analytical processes in the context of the digitalization of the economy", 153-157 (2019).

14. I.F. Karpova, L.V. Dontsova, Materials of an inter-university collection of scientific papers and the results of joint research projects "Accounting, control and analytical processes in the context of the digitalization of the economy", 158-164 (2019).

15. Z.V. Kiryanova, E.I. Sedova, Analysis of financial statements (Moscow, Russia, Yurait, 2014).

16. T.I. Melekhina, Everything for an accountant, 8 (176), 10-21 (2006).

17. T.I. Melekhina, Accountant Consultant, 10 (158), 16-23 (2006).

18. L. Trofimova, N. Prodanova et al., Journal of Advanced Research in Dynamical and Control Systems, 11(8 SI), 416-424 (2019). 